\title{
ABORTION: A NEVER-ENDING INTERDISCIPLINARY DEBATE
}

\author{
Szerző: \\ Simó Ferenc Zoltán (PhD.) \\ Eszterházy Károly Katolikus Egyetem \\ (Magyarország) \\ E-mail: \\ simofredz@gmail.com
}

\author{
Lektorok: \\ Mező Ferenc (PhD.) \\ Eszterházy Károly Katolikus Egyetem \\ (Magyarország) \\ Mező Katalin (PhD.) \\ Debreceni Egyetem (Magyarország) \\ ... and two anonymous reviewers
}

Simó, Ferenc Zoltán (2021). Abortion: a Never-Ending Interdisciplinary Debate. Különleges Bánásmód, 7. (3). 85-94. DOI 10.18458/KB.2021.3.85

\begin{abstract}
This study is the second part of the examination, considering the multifaceted feature of debates surrounding the termination of pregnancy. Although we may suppose that the so-called pro-life and prochoice supporters have already paved their rigid ways of thinking with no possibility or hope for any modification, it might come as a surprise to learn that even Christian and Buddhist points of view can be tuned. Health related disciplines, such as psychology keep reflecting on the issues of abortion with more and more emphasis on the post period of it.
\end{abstract}

Keywords: abortion, human rights, psychology, vallás

Disciplines: Psychology

\section{Absztrakt}

ABORTUSZ: EGY VÉGTELEN INTERDISZCIPLINÁRIS VITA

Jelen tanulmány a második része annak a tanulmány sorozatnak, amely a sokszínúségét vizsgálja, annak a vitának, mely a terhesség megszakítást övezi. Habár azt hihetnénk, hogy az úgynevezett "pro-life" (életpárti) és „pro-choice” (választáspárti) tábor képviselói már bebetonozták véleményeiket az abortusszal kapcsolatban, mégis meglepetésként érhet minket az a jelenség, hogy az oly sziklaszilárdnak tủnő álláspont, mint például a keresztény vagy a buddhista nézőpont is képes finomhangolt változásra. Az egészséghez kötődő tudományágak, mint például a pszichológia folyamatosan reflektálnak az abortusz témájára, egyre inkább a megszakítást követô időszakra fókuszálva.

Kulcsszavak: abortusz, emberi jogok, pszichológia, vallás

Diszciplina: pszichológia 
The first part of this study, Right to life in Hungary and in the EU: the ever-troublesome issue of abortion (Simó, 2020), deals with some legal facts and concerns. This is the second part of the examination, which discusses some thoughtprovoking changes in the parties concerned, bearing in mind the multifaceted feature of the ongoing debates and discussions surrounding the termination of pregnancy. (The last part of this trilogy will be the summing up of this issue with an examination, concerning some curiosities).

After considering the enormous number of studies, pamphlets, articles, even blogs on this topic, one may ask nicely: What is the point of this study? Although the enquiry seems valid, it may look as if the enquire might have already refused to realize the intricacy and nuance of the subject. Still, it can be said that one who intends to comprehend the depth how abortion has been treated culturally, politically and historically in the world tradition should first come to terms with many different but interrelated routes. (As far as political changes are concerned, see, for example, Shannon Stettner, Kristin Burnett, and Travis Hay (eds.) (2017) Abortion: History, Politics, and Reproductive Justice after Morgentaler. UBC Press, Vancouver. or. Rita J. Simon (1998): Abortion. Statutes, Policies, and Public Attitudes the World Over. Greenwood Publishing Group, London.) The difficulty of this subject lies in the fact that many scholars feel the urge to take sides, considering their systems of beliefs. To be frank, they are not mistaken, it appears to be more and more difficult not to take sides, and to attempt to offer some more or different ideas or thoughts on this problematic subject, especially, these days when there are more and more heated debates with applying rhetoric only to be sensational, saleable or marketable, not to mention, for example, the growing number of the pandemic related studies on this subject. (See, for instance: Jaime ToddGher and Payal K. Shah (2020) Abortion in the context of COVID-19: a human rights imperative, Sexual and Reproductive Health Matters, 28:1, or Hussein J. (2020) COVID-19: what implications for sexual and reproductive health and rights globally? Sex Reproduction Health Matters. 2020)

Thus, I offer a preliminary study on how, for example, Christianity and Buddhism have shifted its position on this subject, or what might be examined and re-examined by psychology, I also consider some interesting and worthy factors in order to present a wider spectrum on the current status of the debate. (Check, for instance: Herd, P., Higgins, J., Sicinski, K., and Merkurieva, I. (2016). The implications of unintended pregnancies for mental in later life. American Journal of Public Health, 106 (3), 421-429. or Russo, N, (2014). Abortion, unwanted childbearing, and mental health. Salud Mental. 37, 283-289.) Several concerns and inquiries can be addressed in connection with the issue of termination of pregnancy. According to many scholars, these can be the following without offering a full list of them (Bayles and Henley, 1989, 133-135): Is it morally permissible to obtain an abortion? Is abortion ever a violation of the moral rights of the foetus? Should abortion be legally prohibited? Is the choice of obtaining ever the expression of a trait of character (for instance, selfishness)? It seems true that these questions are frequently asked and debated, and they are often answered by detailed studies, either pro-life or prochoice results.

However, Katie Watson examines some important questions that may not be asked as frequently as the above mentioned ones in her book, Scarlet A: The Ethics, Law, and Politics of Ordinary Abortion. Her enquiries relate to the fact that it is estimated that one in five pregnancies in the US ends in abortion. Her analysis focuses on, among many others, the following questions: Why is something so common, which has been legal so long, still a source of shame and secrecy? Why is it so commonly debated by politicians, and so rarely 
revealed from friend to friend, or loved one to loved one? (Watson, 2018). Also, one can find even more thought-provoking pieces and questions, for instance Sherry F. Colb; Michael C. Dorf pose some serious debatable questions, for example: How can somebody who condemns hunting, animal farming, and animal experimentation also favour legal abortion, which is the deliberate destruction of a human foetus? Should legal reforms herald or follow attitudinal changes? Do gruesome images win over or alienate devotees? Is violence ever righteous or ethical? (Colb and Dorf, 2016) As the point of view changes, questions start to be even more provocative and challenging, for example, some, presented by Kate Greasley, are the following: Does the morality of abortion depend on the moral status of the human fetus? Must the law of abortion presume an answer to the question of when personhood begins? Can a law which permits late abortion but not infanticide be morally justified? (Greasley, 2017).

Even this miniature list makes us ponder upon some of them, although one may ask as well: who decides which answer(s) should be accepted or taken into (serious) considerations? Our question looks even more desired when we consider the statements made by some scholars, for instance, Charles C. Camosy argues that „,[w]hile it is true that much has been written about abortion, it turns out that only a tiny minority of pieces are actually worth reading. Most authors have already decided what the answer is before engaging the evidence and arguments, and they use empty rhetoric in an attempt to "win" and impose a particular point of view.

Very few pieces are even aware of what their opponents are actually arguing, much less engaging it in a fair and careful way. The result is confusion andmischaracterization, which, in turn, leads to caricatures and stereotypes; this, in turn, leads to polarization and disengagement." (Camosy, 2015, 12).
In addition to this, he goes on to explain that “[...] one important reason we need a new book about abortion is because (with a few significant exceptions, several of which are cited in this book) most of what is being written just isn't very good." (Camosy, 2015, 12). He seems to warn us to be more cautious about the selection of books to be used as bases of our notion or idea on abortion. For example, Christopher Kaczor, who cannot be found in Camosy's book, can be named as a fine illustration, and, although he does take sides, he also argues that the solution might be appealing to reason rather than religious belief, his The Ethics of Abortion: Women's Rights, Human Life, and the Question of Justice is against the choice of abortion wholeheartedly. His book weighs the major grounds for denying foetal personhood, as well as the views of those who support and protect not only abortion but also infanticide. He also attempts to offer many (non-theological) justifications for the conclusion that all human beings, as well as those in utero, are supposed to be seen and respected as persons. Kaczor also criticises the opinion that abortion is not wrong even though the human foetus is a person. Interestingly enough, his conclusion ends with an unusual discussion of whether artificial wombs may be able to close the abortion dispute. Answering the arguments of defenders of abortion, this book provides reasoned justification for the view that all intentional abortions are morally wrong and that doctors and nurses who object to abortion should not be forced to act against their consciences. (Kaczor, 2010, 139-145).

\section{Religion and abortion: Christianity and Buddhism}

One of the most difficult issues is the burdensome relation between religion and culture, especially, in places like Africa. Culture and religion have been shown to intersect in public attitudes to 
abortion. In their study Kebede MT, Hilden PK and Middelthon AL argue that in Ethiopia, women regarded abortion as being morally and socially menacing and risky owing to cultural and religious norms regarding abortion. (Kebede, 2012). As a result of this attitude, those in the study can easily be stigmatized and isolated in their own culture with no or less security either emotionally or even physically.

\section{Christianity (or the West)}

Basically when one intends to define the core values of Christianity, we need to take an historical approach. The definition usually denotes (basic) values coming from the teachings of Jesus Christ. The term has numerous presentations, uses and meanings, and detailed (or "precise") definitions might be different between geographical locations and different schools of thought, giving us an extra challenge to stick to it. The terms Christian values and family values are often used as a euphemism for the priority of the family, in the sense that, instead of the governments (or other authorities), families have to take full responsibilities to take care of the members of the families by the Christian right. In addition to this, Christian values can be related to the Christian identity in identity politics. During the course of its history the Catholic Church has taken positions on many subjects that are in one sense political, but in another sense are primarily moral, such as contraception, homosexuality, and divorce. James Hitchhock claims that abortion divides not only the United States, but Catholics all around the world, too. Visibly, these issues must be addressed by Catholics and they feel the need to them within the framework of a democratic society, such as the United States that has no official religion, these ideas might be seen and dealt with in, for instance, Italy, Ireland and Poland, where the influence of the Church may not be overlooked. His book can be seen as a unique perspective with being a study of opposing American Catholic attitudes to abortion, particularly, in connection with laws and government policies. After the ruling of Roe vs. Wade, many pro-life campaigners or supporters have changed and stand without being sentimental and morally allied with Democrats. For the first time, Catholics, as an entire group, have got tangled in U.S. politics. Abortion now is one of the major points of division in American Catholicism: a spreading split between liberal Catholic Democrats who attempts to minimize the issue and other Catholics, many of them politically liberal, whose pro-life commitments might have altered them to "assist" and "cooperate" with Republicans. James Hitchcock debates the 2016 presidential campaign and how it transformed an already altered political landscape. $\mathrm{He}$ analyses the Affordable Care Act, LGBT rights, and the questions they raise about religious liberty, considering the religio-political aspects as well. (Hitchcock,2016). His point appears even more challenging and worthy in the light of Andrew R Lewis' book:The Rights Turn in Conservative Christian Politics: How Abortion Transformed the Culture Wars (which was only published a year later, in 2017). As we have seen the debate is still on, but some players and a few major points have already started to be shifted and blurred by either divisions or politics as well.

Changes that have taken place in the Christian world could capture the attention of many scholars, trying to analyse both the reasons and the outcomes of these changes. One of the is Andrew R. Lewis, who paid rivet attention to the shifts in politics related to Christian politics. He claims that "[...] abortion is critical to evangelical politics, elites are able to expand the sphere of their advocacy by tying issues to abortion. In addition, because the pro-life movement has had an active rights-based justification that has grown more important in evangelical circles, the politics of 
abortion have taught evangelicals about the public value of rights-talk. The politics of abortion have contributed directly to both rights learning and rights claiming, and they are a signpost for rights extending.(Lewis, 2017, 28-29). Another study, presented by Michele Dillons, explores how the Church deals with the concern or the matter of abortion as a woman's right. The American and English bishops used arguments similar to those of the Irish, notwithstanding the absence of legal abortion in Ireland. The Polish bishops, however, departed from the pattern evinced by their fellow-bishops and, at least in the document sample used in this study, gave scant attention to women's situation.” (Dillons, 1996, 34-35).

\section{Buddhism (or the East)}

The discussion and dispute to settle the question of the termination of pregnancy can be argued to be mostly led by the West. The ever-growing pile of studies has already polarized the Western culture, dividing almost all walks of life by the dichotomy, pro and against, pro-life or pro-choice, and so on. Scholars have begun to look for different angles to re-contextualize and to reconceptualise the subject of their debate, abortion. Eastern thoughts, philosophy have started to be filtered into the minds and hearts of those related to or pondered upon the resolution(s).

Although Buddhism has obviously a "pro-life" position on abortion, the final decision is supposed to be left to the pregnant woman. The heated debate on the termination of pregnancy rages on. James Hughes argues that the core Buddhist text do not necessarily stick to rigidly to their doctrinal elements by offering limited views on the outside world, thus, as a consequence, Buddhists need to address and face contemporary issues, problems in the spirit of their teachings, with considering a possible difference, according to their laws. (Hughes, 1998). Abortion is debatably the most controversial and conflict-ridden moral issue of our times, but up until now the dispute has taken place virtually within a Western cultural, religious and philosophical context. For several decades in the West arguments and (harsh) opinions both for and against termination of pregnancy have been amassed up by groups of all sorts, from religious fundamentalists to radical ideologists, feminists and all shades of views and ideas in between. These opposing sides have failed to understand each other mutually, and as a result of this, opinions have been polarized and a trench war has emerged again. In the light of this stalemate a novel standpoint is needed (Keown, 1988).

This in-between situation has created more misunderstanding and clichés by employing, for instance, scholars and politicians, offering inter and multidisciplinary views. Keown Damien also claims that Buddhism is an ancient tradition which over the centuries has distinguished and cultured its unique systems of beliefs and values in the course of a long interaction with the major cultures of Asia. Since Buddhism goes on to capture the rivet attention of the West, it is high time for its views on abortion to be taken into serious considerations, including the examination of a wide range of Buddhist cultural and ethical viewpoints. (See: Barnhart, M. (1998). Buddhism and the morality of abortion. Journal of Buddhist Ethics 5,276-297.) While debating ethical problems or concerns, particularly those concerning Buddhism, one may not be able to isolate a problem from its social and cultural milieus (See Keown, 1998 and LaFleur, 1994). According to the core philosophy is that everything is interrelated or interconnected, and this appears to be understood in this context that issue such as whether termination of pregnancy is right or wrong (or immoral) is a multifaceted one and should not be answered by reading sacred texts alone. 
As far as abortion is concerned, it seems difficult to reason the fact that a country so strongly influenced by Buddhism's worship and devotion for life allows legalized, commonly practised abortion. In addition to this mystery or riddle, it appears that another practice is even more mysterious in the eyes of most Westerners, the Japanese practice of mizuko kuyo (rites) (water child memorial service), in which the parents of aborted foetuses pray for the well-being of these disallowed "lives." Also, it is defined as a Japanese Buddhist ceremony for those people who have experienced miscarriage, stillbirth, or abortion. (Smith, 1992). William LaFleur examines abortion provocatively as a hole-in-the-wall or an opening on the culture and ethics of Japan. At the same time, he contributes to the Western debate on abortion, exploring how the Japanese resolve their conflicting emotions privately and avoid the prolife/pro-choice politics that divide Americans sharply on the issue (LaFleur,1992). The difference between Christianity and Buddhism cannot be blurred or neglected, although LaFleur that $[\ldots .$. Westerners who have lived in Japan-including persons who are Christian-have increasingly come to the view that there is an appreciable level of psychological and spiritual sanity in the practices of mizuko kuyo and that aspects of these practices should be introduced into Western society and the ambit of the West's religious modalities. Although, given the official positions of the Roman Catholic Church on abortion, there is a reluctance to articulate such things overtly, a growing number of Catholics in Japan, I am told, have an interest in exploring what of the mizuko kuyo could be transferred into Christianity. (To get to know more on mizuko kuyo, see: Brooks. A. P. (1981) Mizuko Kuyo' and Japanese Buddhism. Japanese Journal of Religious Studies 8 / 3-4 September-December.) There are also, it appears, members of the clergy who share this interest, and this all seems to arise from a sense that the churches that condemn abortion wholeheartedly and "passionately" have in various examples demonstrated being unreasonable and impractical (LaFleur,1992, 215-216). His statement may seem a bit far-fetching for some, though I assume considering the post-abortion mental state spirituality or religious practices may trigger some level of stability for those involved.

\section{Abortion and psychology}

One of the organizations, Planned Parenthood Federation of America (a non-profit organization that provides sexual health care in the United States and globally), has already altered some major issues by declaring that it is no longer true the legally induced termination of pregnancy does not create mental health problem for women. [https://www.plannedparenthood.org/

There are more and more organizations offering help for women under the pressure related to pre or post period of the termination of pregnancy, but their importance lies in the fact that they have already realized the necessity to re-evaluate the abortion related mental health problems [visit, for example, https://prochoice.org/ or https://europeabortionaccessproject.org/].

One of the most significant attempts to re-visit the mental and emotional issues associated with abortion was in 2011when the Academy of Medical Royal Colleges (AMRC) in London reviewed all studies about the emotional effects of abortion that had been published in English between 1990 and 2011. Most of the studies in the AMRC's rigorous, systematic review were conducted in the United States. From the evidence and limitations within this broad range of studies, researchers concluded that"

- Unwanted pregnancy increases a woman's risk of problems with her mental health.

- A woman with an unwanted pregnancy is as likely to have mental health problems from abortion as she is from giving birth. 
- A woman with a history of mental health problems before abortion is more likely to have mental health problems after abortion.

- Circumstances, conditions, behaviours, and other factors associated with mental health problems are similar for women following abortion and women following childbirth.

- Pressure from a partner to terminate a pregnancy, negative attitudes about abortion, and negative attitudes about a woman's experience of abortion may increase a woman's risk of mental health problems after abortion." (AMRC, 2011)

After its thorough revision, AMRC advises the scholars and scientist to put more emphasis on the mental health consequences and aftermath of unwanted pregnancy. Although, it appears simple it is even more complicated the one has ever thought of. Since AMRC is only one in the line of debates, which has started on the mental effects of abortion. The polarization based on whether the terms, "post-abortion trauma," "post-abortion syndrome," or "post-abortion survivor syndrome," exist at all. One of the authorities, American Psychological Association (APA) concludes that legal abortion does not create psychological risk for most women experiencing abortion and they also state that those times it was about 21 percent of all American women had an abortion, if severe emotional responses were common there would be an epidemic of women seeking psychological treatment. There is no evidence of such an epidemic (Adler, 1989).

Since 1989, there has not been noteworthy change in this point of view. But the debate surrounding the "mystery" of post-abortion period is still going on. (See, for instance: Jones, Rachel K., and Jenna Jerman. (2014). "Abortion Incidence and Service Availability in the United States, 2011."
Perspectives on Sexual and Reproductive Health, 46(1).

Other scholars, such as Katrina Kimport, Kira Foster and Tracy A. Weitz have found evidence for emotional difficulties. After summing up the result of their semi-structured, in-depth telephone interviews, they argue that "[f]or many respondents, having an unplanned pregnancy and abortion were emotionally complicated experiences, made particularly difficult by two social processes: the decision-making process before the abortion and the process of finding social support afterwards." (Kimport K, Kira Foster K and Tracy A. Weitz, 2011).

As we have already seen it, the lack of social support may be able to contribute to burdensome experiences, and, as a result, it might give way to problems with psychological roots. Katie Watson's observations may be able to contribute to the changes, since she argues that even if abortion turned out to a constitutional right by the Roe v. Wade decision well-known by most scholars, termination of pregnancy remains a stigma, or as she calls it, a proverbial scarlet $A$, in the United States. (The scarlet A seems a reference to The Scarlet Letter, a Romance written by Nathaniel Hawthorne, a story of Hester Prynne, who (after an affair) gives birth to her daughter and refuse to provide the name of the father. the major theme of this story can be describe as stigmatization by the society and humiliating.) Katie Watson's book searches the personal stigma that prevents several women from sharing their abortion experiences with friends and family in private conversation, and the structural stigma that keeps it that way. She also states that America could benefit from working to reverse such stigma. She mostly blames public discourse having the potential to distort and create silence around private experience with abortion. Although, as we have already discussed it, the conclusion of APA makes it "clear" that legal termination of pregnancy does not create 
psychological risks for women experiencing it, some scholars may disagree. In their study, Korenromp,M.J., G. C. M. L. Christiaens, J. van den Bout, E. J. H. Mulder, J. A. M. Hunfeld,C. M. Bilardo, J. P. M. Offermans and G. H. A. Visser have evaluated the psychological consequences of termination of pregnancy for foetal anomaly in women. The assessment took place between 2 and 7 years after the event. Large variation was found in symptoms of grief and posttraumatic stress. Women generally adapted well with respect to grief, but a substantial number of participants showed pathological scores for posttraumatic stress. Significant risk factors for poor psychological outcome were a low level of education and a low level of perceived partner support. A modest, but consistent, association was found between advanced gestational age and the level of distress. Women with pathological responses were equally distributed over the 5 years of study." (Korenromp, et al., 257). The complexity of their findings on the termination of pregnancy for foetal anomaly lies in the fact that abortion can be linked to long-term psychological consequences for a considerable number of women. Clinically relevant determinants are gestational age, perceived partner support, and educational level.

Tran Minh Hang states that "[....] women's silent suffering and abortion related fears are key barriers to their effective access to reproductive health care," and she also claims that "[....] the physical, social, psychological and spiritual suffering women experience after sex-selective abortion and the obstacles they face in receiving adequate care and understanding." [Hang,2011,127-128] In addition to this, her examination has revealed that [s]ome women experienced these [psychological] problems for only a short period, but many others had emotional difficulties long after their abortion. In many cases, the women experienced nightmares, depression and other kinds of trauma for years.
(Hang,2011,132) Brenda Major, Mark Appelbaum, Linda Beckman, Mary Ann Dutton, Nancy Felipe Russo, and Carolyn West have evaluated empirical research and studies on abortion and mental health, and they argue that there are methodological problems can be found because it matters how enquiries are framed, they state that "[....] how researchers frame this question shapes the findings that are obtained and how they are interpreted. Too often, the question is framed in a way that implies that abortion is a unitary event, experienced similarly by all women. Abortion, however, encompasses a diversity of experiences, and women vary significantly in how they react to this life event. Understanding the personal, social, and cultural sources of this variability is important if we are to fully appreciate how abortion affects women's mental health. Understanding the mental health implications of abortion also requires that we compare psychological responses associated with abortion with psychological responses associated with its real alternative other courses of action that might be taken by a pregnant woman in similar circumstances (i.e., facing an unwanted pregnancy). Failing to do so sets up a false comparison and ignores the reality of women's lives-once a woman is faced with an unwanted pregnancy, or one she feels financially, emotion. (Major B, et al, 2009. 863-890). It is an impossible mission to define the wide range of emotions each and every woman experiences after the process of abortion, and, as we could learn from these studies, women's physical recovery, psychological and therapeutic healing and the post abortion care heavily depend on and can be affected by social, cultural, political, economic and religious factors.

\section{Conclusion}

Although Charles C. Camosy states that there is not much left to write and discuss on abortion, and there are not too many pieces to be considered praiseworthy, their might be some hope to keep 
the ball rolling. Even if he assumes that many who have written on the subject "[....] use empty rhetoric in an attempt to "win" and impose a particular point of view. Very few pieces are even aware of what their opponents are actually arguing, much less engaging it in a fair and careful way." (Camosy, 2015, 12). One may not be surprised by the result, which I agree, can be described as misperception and misleading characterization, which, in turn, leads to misrepresentations and labels and stigmas as Katie Watson describes. Of course, this might be the cause of the polarization and detachment on this subject, though one might find other reasons, such as political, religious or cultural and so on. Camosy appears to warn us to be more thoughtful and alert about the selection of sources to be used as bases of our notion or idea on abortion. This might be true but the abundance of choices may not make the task of the reader easy, especially, on a topic such as the termination of pregnancy, although the exploration of mizuko kuyo as transferred into Christianity would be a fascinating and provocative task. Though we might try to be neutral on this subject, which seems almost impossible, one may add that the statement of not having psychological difficulties after a legal termination of pregnancy might not be too realistic, even if some of the studies conclude so. This study merely attempts to scratch the surface of the changes taken place recently, offering a selection of thoughts for its readers.

\section{References}

Adler, Nancy E. (1989). University of California at San Francisco, Statement on Behalf of the American Psychological Association Before the Human Resources and Intergovernmental Relations Subcommittee of the Committee on Governmental Operations, U. S. House of Representatives: 130-40.
Adler, Nancy E., et al. (1990). "Psychological Responses after Abortion." Science, 248(4951), 41-4. doi 10.1126/science. 2181664

AMRC - Academy of Medical Royal Colleges. (2011). Induced Abortion and Mental Health A Systematic Review of the Mental Health Outcomes of Induced Abortion, Including Their Prevalence and Associated Factors. London: Academy of Medical Royal Colleges/National Collaborating Center for Mental Health.

Barnhart, M. (1998). Buddhism and the morality of abortion. Journal of Buddhist Ethics 5, 276-297.

Bayles, M. D., and Henley, K. eds. (1989). Right Conduct: Theories and Applications. Random House, New York.

Brooks. A. P. (1981) Mizuko Kuyo' and Japanese Buddhism. Japanese Journal of Religious Studies 8 / 3-4 September-December.

Camosy, C.C. (2015). Beyond the Abortion Wars: $A$ Way Forward for a New Generation-Wm. B. Eerdmans Publishing Co. Michigan.

Charles, Vignetta E., et al. (2008). "Abortion and Long-Term Mental Health Outcomes: A Systematic Review of the Literature." Contraception, 78, 436-50.

Coleman, Patricia K. (2011). "Abortion and Mental Health: Qualitative Synthesis and Analysis of Research Published 1995-2002." The British Journal of Psycbiatry, 199, 180-6.

Dilon, M (1996). Cultural Differences in the Abortion Discourse of the Catholic Church: Evidence from Four Countries: Sociology of Religion, Spring, 1996, Vol. 57, No. 1, Special Issue: Sociology of Culture and Sociology of Religion (Spring, 1996), pp. 25-36 Published by: Oxford University Press. Oxford.

Hughes J. (1998) Buddhism and Abortion: A Western Approach. In: Keown D. (eds) Buddhism and Abortion. Palgrave Macmillan, London doi 10.1007/978-1-349-14178-4_9 
Greasley, Kate: (2017) Arguments about abortion: personhood, morality, and law. Oxford University Press, Oxford.

Hang, T. M. (2011) Global Debates, Local Dilemmas: Sex-selective Abortion in Contemporary Viet Nam. Australian National University. Canberra.

Hitchcock. J. (2016) Abortion, Religious Freedom, and Catholic Politics. Transaction Publishers, London.

Hussein J. (2020) COVID-19: what implications for sexual and reproductive health and rights globally? Sex Reprod Health Matters. 2020. doi 10.1080/26410397.2020.1746065

Kaczor, C. (2010) The Ethics of Abortion: Women's Rights, Human Life, and the Question of Justice. Routledge, London.

Kebede MT, Hilden PK and Middelthon AL. (2012) The tale of the hearts: deciding on abortion in Ethiopia. Culture, health and sexuality. 14(4):393-405.

doi 10.1080/13691058.2011.649495

Keown D. (eds.) (1998) Buddhism and Abortion. Palgrave Macmillan UK, London.

Kimport K, Kira Foster K and Tracy A. Weitz (2011): Social Sources of Women's Emotional Difficulty After Abortion: Lessons from Women's Abortion Narrative. Perspectives on Sexual and Reproductive Health, JUNE, Vol. 43, No. 2. 103-109. doi 10.1363/4310311

Korenromp, M.J, G. C. M. L. Christiaens, J. van den Bout, E. J. H. Mulder, J. A. M. Hunfeld, C. M. Bilardo, J. P. M. Offermans and G. H. A. Visser. (2005) Long-term psychological consequences of pregnancy termination for fetal abnormality: a cross-sectional study. John Wiley and Sons, Ltd. Prenatal Diagnosis 2005; 25: 253-260. doi 10.1002/pd.1127
LaFleur. W. R. (1992) Liquid Life: Abortion and Buddhism in Japan. Princeton University Press, Princeton.

Lewis A. R. (2017) The Rights Turn in Conservative Cbristian Politics: How Abortion Transformed the Culture Wars. Cambridge University Press. Cambridge.

Major B, Appelbaum M, Beckman L, Mary Ann M, Dutton M.N, Nancy, Felipe Russo N.F and West,C.(2009) Abortion and Mental Health: Evaluating the Evidence. American Psychologist Vol. 64, No. 9, 863-890. doi 10.1037/a0017497 Smith, B. (1992). Buddhism and Abortion in Contemporary Japan: Mizuko Kuyo and the Confrontaion with Death. SUNY PRESS. New York.

Simó, F. Z (2020). Right to Life in Hungary and in the EU: the Ever-Troublesome Issue of Abortion. Különleges Bánásmód, 6. (4). 83-90. doi $\underline{10.18458 / K B .2020 .4 .83}$

Todd-Gher J and Shah P. K. (2020) Abortion in the context of COVID-19: a human rights imperative. Sexual and Reproductive Health Matters, 28:1, 1758394, doi $\underline{10.1080 / 26410397.2020 .1758394}$

Watson K. (2018) Scarlet A: The Ethics, Law, and Politics of Ordinary Abortion. Oxford University Press, New York.

https://www.plannedparenthood.org/ https://prochoice.org/ https:/ / europeabortionaccessproject.org/ 